\title{
Effect of storage levels of nitric oxide derivatives in blood
}

\section{components [version 1; peer review: 5 approved]}

\section{Melissa A Qazi1, Fabiola Rizzatti1,2, Barbora Piknova1, Nathawut Sibmooh1,3, David F Stroncek ${ }^{4}$, Alan N Schechter ${ }^{1}$}

\author{
${ }^{1}$ Molecular Medicine Branch, National Institutes of Diabetes and Digestive and Kidney Diseases, National Institutes of Health, \\ Bethesda, MD 20892, USA \\ ${ }^{2}$ Federal University of São Carlos, São Paulo, Brazil \\ ${ }^{3}$ Department of Pharmacology, Faculty of Science, Mahidol University, Rama 6 Rd., Payathai Rajathewee, Bangkok 10400, Thailand, \\ Thailand \\ ${ }^{4}$ Department of Transfusion Medicine, National Institutes of Health, Bethesda, MD 220892, USA
}

\section{V1 First published: 22 Oct 2012, 1:35 \\ https://doi.org/10.12688/f1000research.1-35.v1}

Latest published: 22 Oct 2012, 1:35

https://doi.org/10.12688/f1000research.1-35.v1

\section{Abstract}

Background: Potential deleterious effects of red blood cell (RBC) transfusions, especially from blood kept at length, have been ascribed to biochemical changes during storage, including those of nitric oxide (NO) metabolism.

Study methods and design: In this study, NO metabolites, nitrite and nitrate, were quantified in RBCs and whole blood with time of storage. Whole blood (WB), leukoreduced (LR), and non-leukoreduced (NLR) components were obtained from healthy volunteer donors and stored in polyvinyl chloride bags for 42 days. Nitrite and nitrate were measured using reductive gas-phase chemiluminescence.

Results: Nitrite concentrations initially decreased rapidly from about $150 \mathrm{nmol} / \mathrm{L}$, but stabilized at about $44 \mathrm{nmol} / \mathrm{L}$ in room air for up to 42 days. Nitrate concentrations remained stable during storage at about $35 \mu \mathrm{mol} / \mathrm{L}$. Cells from bags maintained in an argon chamber showed decreased nitrite levels compared to those maintained in room air. Inhibition of enzymes implicated in the NO cycle did not alter nitrite levels.

Conclusion: As erythrocytes may contribute to the control of blood flow and oxygen delivery through reduction of nitrite to NO under hypoxic conditions, the present findings provide insight into possible effects of blood transfusion. These measurements may explain some adverse effects of RBC transfusion and suggest ways of optimizing the preservation of stored blood.

\section{Open Peer Review \\ Approval Status

$\begin{array}{lllll}1 & 2 & 3 & 4 & 5\end{array}$ \\ version 1 \\ 220ct 2012 view $\checkmark \checkmark$ view view \\ 1. Andre Dejam, Brigham and Women's \\ Hospital, Boston, MA, USA \\ 2. Jon O. Lundberg, Karolinska Institutet and Hospital, Stockholm, Sweden \\ 3. Eddie Weitzberg, Karolinska Institutet and Hospital, Stockholm, Sweden \\ 4. Malte Kelm, University Duesseldorf, Duesseldorf, Germany \\ 5. Jay Zweier, The Ohio State University, Columbus, $\mathrm{OH}$, USA}

Any reports and responses or comments on the article can be found at the end of the article. 
Corresponding author: Alan N Schechter (aschecht@helix.nih.gov)

Competing interests: Alan N Schechter has a patent on therapeutic use of nitrite salts. Melissa A Qazi, Fabiola Rizzatti, Barbora Piknova, Nathawut Sibmooh, and David Stroncek have no conflicts of interest to disclose.

Grant information: The study was funded by and received research support from the Molecular Medicine Branch, NIDDK, NIH and the Department of Transfusion Medicine, Clinical Center, NIH.

The funders had no role in study design, data collection and analysis, decision to publish, or preparation of the manuscript.

Copyright: ( 2012 Qazi MA et al. This is an open access article distributed under the terms of the Creative Commons Attribution License, which permits unrestricted use, distribution, and reproduction in any medium, provided the original work is properly cited. Data associated with the article are available under the terms of the Creative Commons Zero "No rights reserved" data waiver (CCO 1.0 Public domain dedication).

How to cite this article: Qazi MA, Rizzatti F, Piknova B et al. Effect of storage levels of nitric oxide derivatives in blood components [version 1; peer review: 5 approved] F1000Research 2012, 1:35 https://doi.org/10.12688/f1000research.1-35.v1

First published: 22 Oct 2012, 1:35 https://doi.org/10.12688/f1000research.1-35.v1 


\section{Introduction}

The field of transfusion medicine has experienced much controversy surrounding the safety and efficacy of current transfusion practices. Potentially deleterious effects that are seen with blood storageincluding, but not limited to, declines in 2,3-DPG and ATP, as well as increases in potassium content and in free hemoglobin and iron (due to hemolysis of red cells)-have been termed the "storage lesion" $", 2$. Our limited understanding of the significance of this storage lesion or storage-induced physiological changes is at the root of a current debate about the efficacy of using long-stored blood. Reports of post-transfusion complications, such as multiple organ failure, sepsis, and even small general increases in morbidity and mortality, have fueled much concern, ${ }^{1,2}$ but clinical investigation has yielded conflicting opinions about the actual impact of the age of blood on transfusion outcomes. Some studies suggest that transfusion with stored blood results in greater post-operative complications than transfusions with fresh blood because of the deleterious effects of storage $\mathrm{e}^{3-5}$. However, several other studies have presented results that indicate no definitive difference between transfusion outcomes with fresh blood or aged blood, ${ }^{6-8}$ or if there is an effect, it is probably small ${ }^{9,10}$. Infusing stored blood with augmented 2,3-DPG and ATP has resulted in improved transfusion outcomes ${ }^{11}$, and a similar approach is now being considered to target other potentially deleterious biochemical changes.

Among the observed adverse effects of blood transfusions, reduced oxygen delivery and reduced vasodilatory capabilities of stored RBCs are considered especially critical factors ${ }^{1,2,12}$. It is now known that one of the primary vasodilators and regulators of blood flow is the endothelium-derived relaxing factor, nitric oxide (NO) ${ }^{13}$. Substantial production of NO occurs within tissues via several mechanisms. Initially, conversion of L-arginine to $\mathrm{NO}$ was thought to be primarily via endothelial nitric oxide synthase (eNOS) ${ }^{14-16}$ and to a lesser extent, via neuronal nitric oxide synthase (nNOS) and inducible nitric oxide synthase (iNOS) enzymes ${ }^{17}$. It has recently been realized that, in addition to NOS synthesis, nitrite reduction to NO may be catalyzed by the enzymatic action of xanthine oxidoreductase, nonenzymatic disproportionation, and reduction by deoxyhemoglobin in blood and by other heme-proteins in various tissues ${ }^{18-23}$. Indeed, nitrite ions may be the major storage pool of NO bioactivity. On the other hand, erythrocytic hemoglobin is a major sink for the destruction of NO, and cell-free hemoglobin is an even more effective sink for $\mathrm{NO}^{24}$. Clearly the physiological and potentially pathological effects of red cell transfusions will be affected by any changes in these NO synthetic and destructive processes prior to, during, and immediately after red cell administration.

Currently, there is interest in the investigation of potential clinical consequences of changes in NO derivatives during storage, especially with respect to oxygen delivery and vasodilatory capabilities of transfused blood, as well as any association with transfusion-related complications. Two approaches to this have surfaced from our understanding of the metabolism of NO. In one, the nitrite/NO pathway is implicated-nitrite is a major storage pool of NO that can interconvert directly or indirectly with NO. In fact, studies on platelets have elucidated a functional role of nitrite as a modulator of platelet aggregation under hypoxic conditions ${ }^{25,26}$. In another approach, S-nitrosylated hemoglobin ( $\mathrm{SNOHb})$ is implicated-indeed, it was proposed that the amount of $\mathrm{SNOHb}$ is responsible for the quality of stored red cells, and that replenishing $\mathrm{SNOHb}$ would be therapeutically helpful, supposedly restoring the oxygen-transport and vasodilatory capabilities of RBCs. However, this theory has been questioned on several grounds ${ }^{20,27-29}$. Evaluation of NO availability with respect to hemoglobin-mediated reductive mechanisms thus appears warranted.

In the present study, we quantified the main nitric oxide metabolites-nitrite and nitrate-as a function of duration of blood storage. We investigated blood stored under standard blood bank protocols, as well as blood stored in an argon chamber, to prevent gas exchange with the surrounding air. We also addressed the role of enzyme inhibition in NO metabolite composition in stored blood. Our results demonstrated a stable nitrate concentration throughout storage but a gradual decline in nitrite concentration after the initial rapid destruction upon venisection. Stored blood consistently maintained low levels of nitrite until the end of storage. The potential implications of these results for blood transfusion therapies are discussed.

\section{Materials and methods}

\section{Human blood donors and study design}

Ten healthy volunteer donors enrolled in an Institutional Review Board approved protocol each provided one $450 \mathrm{~mL}$ unit of blood for this study. Blood was drawn using the standard phlebotomy method and stored in polyvinyl chloride (PVC) bags for up to 42 days at $4^{\circ} \mathrm{C}$, per standard blood bank protocol. An additional $20 \mathrm{~mL}$ of whole blood was collected in $10.0 \mathrm{~mL}$ Becton Dickinson (BD) Vacutainer ${ }^{\circledR} \mathrm{S}$ for immediate processing. Each single unit of blood was split into units of WB, NLR, and LR blood components. Six units were used to measure changes in WB, LR, and NLR blood samples over 42 days. Three of these units were randomly designated for room air storage and the other three were for argon chamber storage. Supernatants from these six units were used to measure their respective nitrite and nitrate values when stored in either room air or the argon chamber, and small amounts of blood from each bag were used to measure the $\mathrm{pO}_{2}$ levels as well. The four remaining units were used for the enzyme inhibition studies, with 2 units for L-NAME and 2 units for acetazolamide. Each unit was split into LR and NLR control units and LR and NLR units for enzyme inhibitor administration.

To test immediate nitrite decay, a separate pool of donors was used.

\section{Separation of blood components}

Whole blood collected using a citrate phosphate double dextrose anticoagulant (CP2D) PVC bag was split three ways-whole blood (WB), non-leukoreduced (NLR) blood component, and leukoreduced (LR) blood component (see Supplemental Figure 1 for an overview of the protocol). $100 \mathrm{~mL}$ of $\mathrm{WB}$ was drawn into a new PVC bag. The remaining blood in the original CP2D unit was centrifuged and the plasma was removed; these RBCs were mixed with adenine-saline (AS-3) solution and comprised the NLR component. $150 \mathrm{~mL}$ of this unit were filtered through an RCM1 Leukocyte Filter (Pall Corp., East Hills, NY) to obtain the LR component. All components were stored in identical AS-3 PVC bags. Blood separation occurred at 20 to $24^{\circ} \mathrm{C}$ and required approximately 1 hour. 


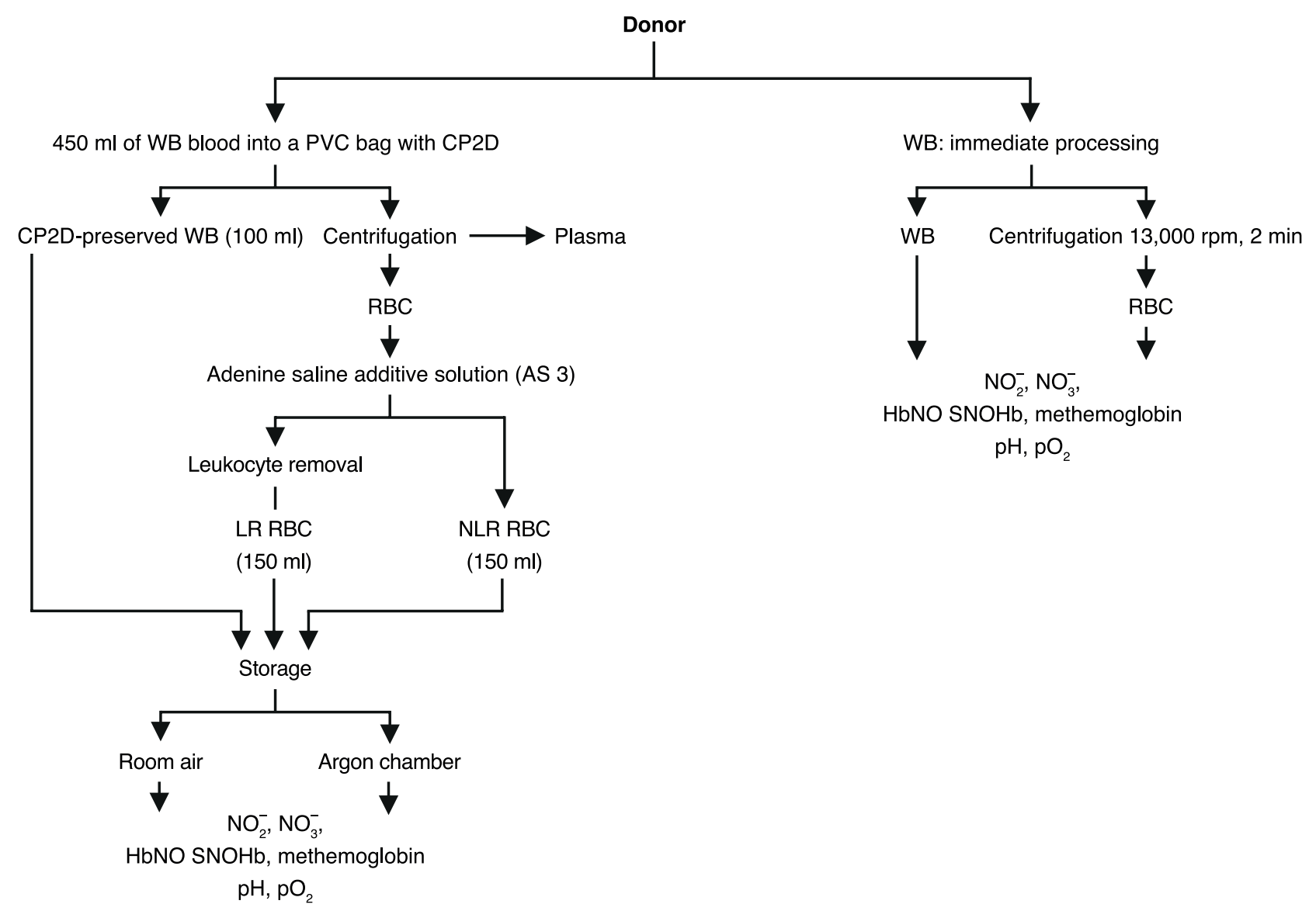

Supplemental Figure 1. Outline of study design.

\section{Blood storage}

Blood components were either stored in room air for 42 days at $4^{\circ} \mathrm{C}$ - standard blood bank storage conditions, or in an air-tight chamber (Fisher Scientific, Vacuum Dessicator Cabinet, Suwanee, GA) for 42 days at $4{ }^{\circ} \mathrm{C}$ in an argon atmosphere (Roberts Oxygen Co., $99 \%$ pure argon, Rockville, MD).

\section{Sample preparation and testing}

Samples were collected for analysis of nitrite, nitrate, $\mathrm{SNOHb}$, iron nitrosyl hemoglobin (HbNO), and methemoglobin (MetHb) in all components. Immediately upon venisection, baseline samples of heparinized WB and RBC were taken. Aliquots of blood were thereafter drawn from storage bags using a liquid transfer set (Charter Medical, Winston-Salem, NC) to maintain sterile conditions. Three replicates of each sample were collected in Eppendorf tubes everyday for the first seven days of storage, and every 2-3 days following that, until day 42 . Upon collection, samples were placed on dry ice and maintained in a $-80^{\circ} \mathrm{C}$ freezer until thawed on regular ice prior to chemiluminescent analysis. An Abbott i-STAT cartridge reader (Abbott Laboratories Inc., Portable Clinical Analyzer, East Windsor, $\mathrm{NJ}$ ) was used to determine $\mathrm{pH}$ and $\mathrm{pO}_{2}$ levels (using $\mathrm{CG}^{+}$ and $\mathrm{G}^{+}$cartridges) at the time of sample collection.

\section{Blood nitrite and nitrate}

A standard protocol was used to determine $\mathrm{NO}_{2}^{-}$and $\mathrm{NO}_{3}^{-}$levels in the three blood components ${ }^{30,31}$. "Stop solution" $\left(\mathrm{K}_{3} \mathrm{Fe}(\mathrm{CN})_{6}\right.$, N-ethylmaleimide, water, NP40) was added to blood to maintain nitrite levels until sample analysis ${ }^{21}$. A 1:4 dilution of "stop solution" to blood was vortexed and placed on dry ice. At the time of sample analysis, a 1:1 dilution of $99.9 \%$ pure methanol and thawed sample was centrifuged for $2 \mathrm{~min}$ at $13,000 \mathrm{rpm}$; the supernatant was immediately injected into the chemiluminescent nitric oxide analyzer (NOA, Sievers, Model 280 NO analyzer, Boulder, CO) using helium as the carrier gas. The triiodide $\left(\mathrm{I}_{3}^{-}\right)$ozone-based chemiluminescent assay was used to analyze nitrite levels. To analyze nitrate, deionized water (Millipore CQ-Gard, Bedford, MA) was added to blood to lyse cells. A 9:1 dilution of deionized water to blood was vortexed and placed on dry ice. At the time of sample analysis, a 3:1 dilution of pure HPLC grade ethanol and thawed sample was centrifuged, and the supernatant was immediately analyzed using the Vanadium(III)chloride chemiluminescent assay. The $\mathrm{VCl}_{3}$ reaction solution was maintained at $90^{\circ} \mathrm{C}$ with helium as the carrier gas. $1 \mu \mathrm{M}$ nitrite and nitrate solutions were used to generate standard curves for comparisons and adjustments of sample nitrite and nitrate concentrations. 


\section{$\mathrm{SNOHb} / \mathrm{HbNO}$}

A standard protocol was used to determine $\mathrm{SNOHb}$ and $\mathrm{HbNO}$ levels in all components ${ }^{30,31}$. A thiol-stabilization solution (NEM-DPTA; $\mathrm{K}_{3} \mathrm{Fe}(\mathrm{CN})_{6}$, N-ethylmaleimide, Diethylenetriaminepenta acetic acid, NP40, water) was added to blood to maintain $\mathrm{SNOHb}$ and $\mathrm{HbNO}$ levels by inhibiting additional thiol reactions. A 4:1 dilution of NEM-DPTA to blood was vortexed and placed on dry ice. A 9:1 dilution of sample and 5\% acid sulfanilamide (AS) was incubated for $5 \mathrm{~min}$; half was injected into the $\mathrm{NOA}\left(\mathrm{I}_{3}{ }^{-}\right.$assay) to give combined $\mathrm{SNOHb}$ and $\mathrm{HbNO}$ levels. The remaining sample was incubated with $50 \mathrm{mM} \mathrm{HgCl}_{2}$, then incubated again with $5 \% \mathrm{AS}$, and injected into the NOA to give HbNO levels.

\section{Supernatants and saline}

Blood components were centrifuged at $13,000 \mathrm{rpm}$ for $5 \mathrm{~min}$ and WB, NLR, and LR supernatants were collected. Aliquots of saline were collected directly from control PVC bags using a liquid transfer set. The aforementioned $\mathrm{I}_{3}^{-}$and $\mathrm{VCl}_{3}$ assays were used for $\mathrm{WB}$, NLR, and LR supernatants and saline samples. As samples were already separated from the blood pellet, treatment with methanol and ethanol was unnecessary.

\section{Methemoglobin}

Methemoglobin (MetHb) analysis was performed at each sample collection. Pre-storage and storage values (up to 42 days) were evaluated using a CO-Oximeter (Radiometer America Inc., OSM3 Hemoxymeter, Cleveland, $\mathrm{OH}$ )

\section{Nitrite decay}

Fresh whole blood collected in heparinized Vacutainer ${ }^{\circledR} \mathrm{S}$ was immediately sampled for pre-storage nitrite and nitrate levels using the aforementioned protocols. The first 5 hours of ex vivo $\mathrm{NO}_{2}^{-}$decay was studied for WB and RBCs only. Aliquots were collected at time $=0,5,10,15,20,30,60,120,180,240$, and 300 (in minutes), where time points do not account for a 3-5 minute delay in receiving samples from the phlebotomist. $1 \mathrm{~mL}$ of whole blood was centrifuged at $13,000 \mathrm{rpm}$ for $2 \mathrm{~min}$ at each interval to obtain RBCs.

\section{Enzyme inhibition}

Bags of LR and NLR RBCs were stored for 7 days and infused once daily with one of three inhibitors: N-Nitro-L-arginine methyl ester hydrochloride (L-NAME, PBS; final concentration: 1mM, SigmaAldrich Co.) ${ }^{32}$ for NOS inhibition, acetazolamide (acetazolamide, DMSO; final concentration: $100 \mu \mathrm{M}$, Sigma-Aldrich Co. $)^{33}$ for carbonic anhydrase inhibition, and oxypurinol (oxypurinol, $\mathrm{NaOH}$, Tris-Ringer buffer; final concentration: $0.1 \mathrm{mM}$, Sigma-Aldrich Co.) $)^{34}$ for xanthine oxidase inhibition. All inhibitors were administered using a liquid transfer set. Controls were infused once daily with identical saline volume. Blood and supernatant samples were prepared 1 hour after infusion and tested per the aforementioned methods for nitrite analysis.

\section{Data analysis}

Data were recorded using the NOAnalysis 3.21 Liquid software. OriginLab 7 was used to analyze data and calculate the amount of NO detected, by evaluating the area under the peaks and comparing them to known standards. Nitrite and nitrate values were corrected by subtracting the amount of nitrite present in methanol and stop solution, and the amount of nitrate in ethanol and water, respectively. $\mathrm{SNOHb}$ was determined by subtracting $\mathrm{HbNO}$ levels from cumulative $\mathrm{HbNO}$ and $\mathrm{SNOHb}$ levels.

\section{Statistical analysis}

GraphPad Prism 4 was used for statistical analysis and graphical representation of data (mean \pm SEM). A one-way ANOVA test with the Bonferroni multiple comparison analysis was used to determine statistical significance. Results with a p-value of less than 0.05 were considered significant.

\section{Results}

Changes in nitrite levels over the duration of storage

Nitrite levels showed the expected very rapid decay in both whole blood and red blood cells in the hours immediately following venisection (Figure 1). Blood was kept in air at room temperature for the duration of these measurements. At $t=0$, the nitrite concentration in whole blood (Figure 1A) was about $150 \mathrm{nM}$; by $60 \mathrm{~min}$, endogenous blood nitrite levels had decreased to about $85 \mathrm{nM}$, and by 5 hours, nitrite levels had decreased to about $65 \mathrm{nM}$. The values for the first 60 minutes are consistent with previously reported data $^{21}$. Red blood cell preparations, in which the first measurements were delayed by the processing time (approximately 3-5 minutes after receipt from the phlebotomist), demonstrated comparable behavior (Figure 1B), but the higher initial values were lost during this time.

Nitrite underwent additional, but slower decay in all three product forms and their supernatants over 42 days of storage, but the nitrite concentration leveled off in room air samples at about 44nM (Figure 2A) in all three blood components. This gradual decrease in concentration and leveling was found in both air and argon chamber stored blood (Figure 2B). However, comparison of blood nitrite levels from air (Figure 2A) and the argon chamber (Figure 2B) reveals a noticeable depression in nitrite values in the chamber environment that is consistent throughout the storage period. RBCs stored in room air had nitrite concentrations of $42 \pm 4 \mathrm{nM}$ on day 42 ; while the argon chamber samples decreased in concentration to $16 \pm 3 \mathrm{nM}$ on day 42. WB stored in room air reached nitrite concentrations of $44 \pm 8 \mathrm{nM}$, while WB stored in the chamber reached nitrite concentrations of $26 \pm 3 \mathrm{nM}$ by the end of the storage period $(\mathrm{p}>0.05)$. Under both storage conditions, nitrite levels were very similar (within the error of this assay) for the three types of cell preparations-whole blood, non-leukoreduced RBCs, and leukoreduced RBCs-for the duration of the experiment (Supplemental Figure 2). However, the higher values in room air as compared to chamberstored samples suggest additional factors affecting production and/or destruction of nitrite ions. Supplemental Figure 2 presents curve-fitting of these data, displaying room air and chamber nitrite decay for the individual blood components. The same trends were seen in the nitrite concentrations of supernatants for each of the three blood components (Figure 3A and 3B). Nitrite concentration in supernatants was significantly lower than that in blood components, confirming nitrite localization in erythrocytes and the findings of previous studies ${ }^{21}$.

In saline stored in PVC bags, nitrite levels varied greatly based on storage conditions (Figure 3C). Saline stored in room air experienced 
A

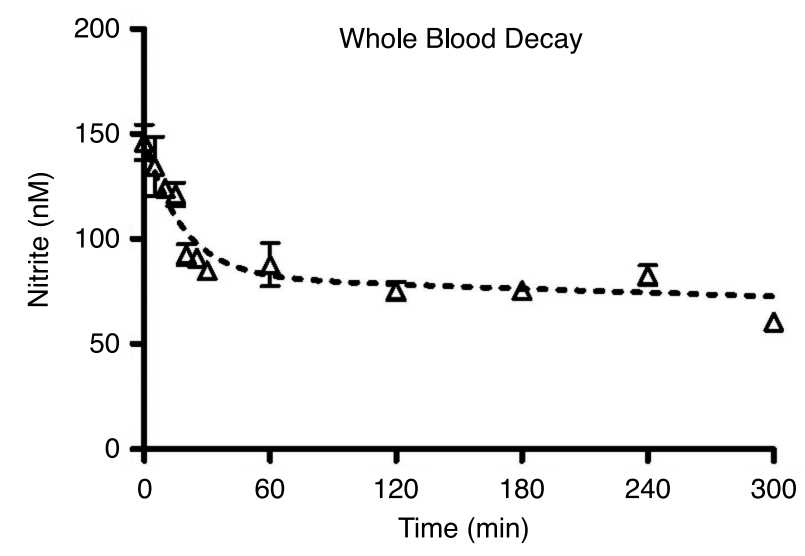

B

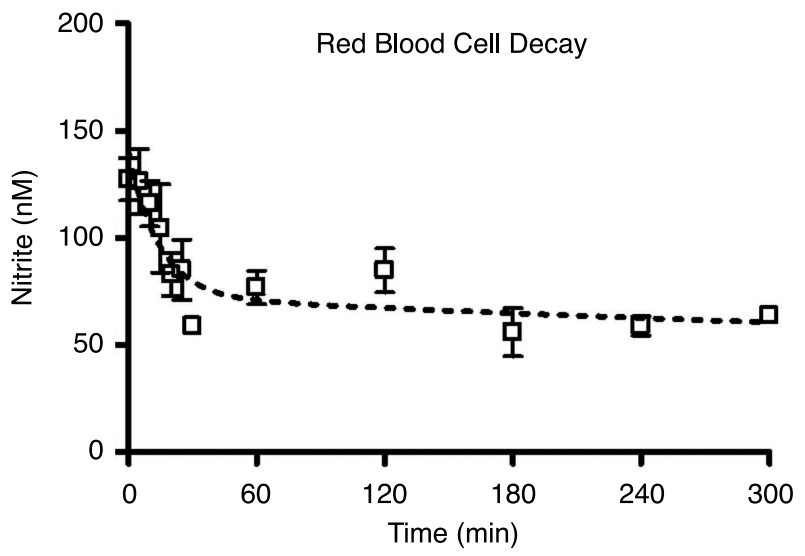

Figure 1. Whole blood (1A) and red blood cell (1B) nitrite decay over the first $\mathbf{5}$ hours following blood draw. Blood components were kept in room air at $24^{\circ} \mathrm{C}$; number of donors, $n=6(\mathbf{A}), n=4(\mathbf{B})$. Time points above do not account for a $3-5$ minute delay in receipt of blood from phlebotomist.

Changes in whole blood and red blood cell nitrite levels over the duration of storage

2 Data Files

http://dx.doi.org/10.6084/m9.figshare.96383
A

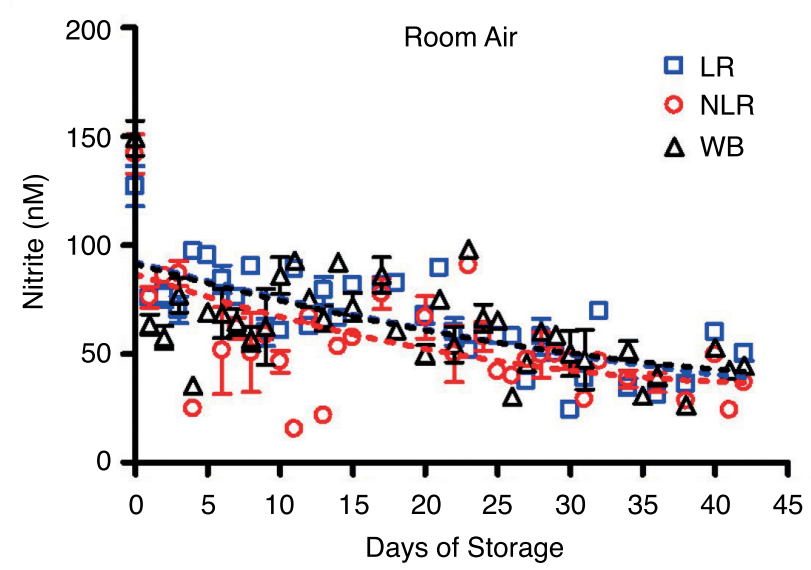

B

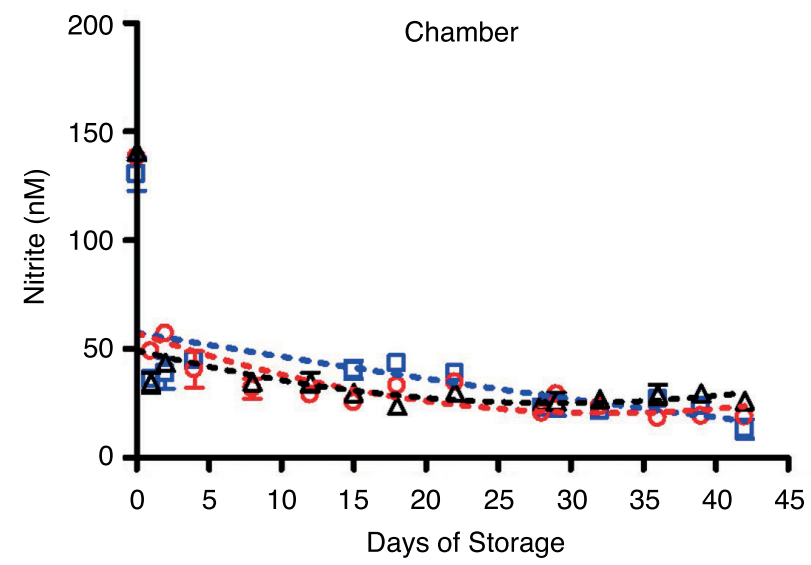

Figure 2. Time-dependent changes in nitrite concentration during storage. Blood components stored in the three forms noted were kept for 42 days at $4^{\circ} \mathrm{C}$ in either room air $(\mathbf{2 A})$ or an argon chamber $(\mathbf{2 B})$, to emulate aerobic and hypoxic conditions, respectively; number of donors, $n=3(\mathbf{A}), n=3(\mathbf{B})$.

Changes in the three blood forms nitrite levels over the duration of storage

2 Data Files

http://dx.doi.org/10.6084/m9.figshare.96384 
A

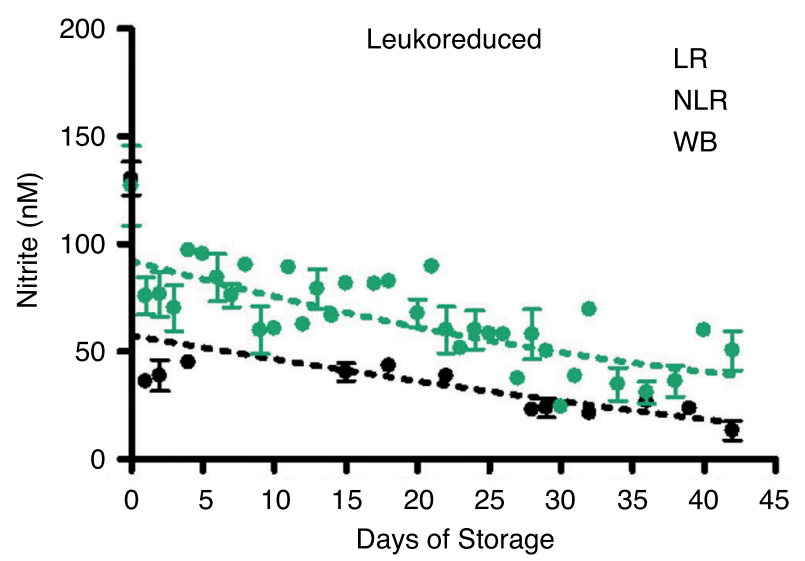

C
B

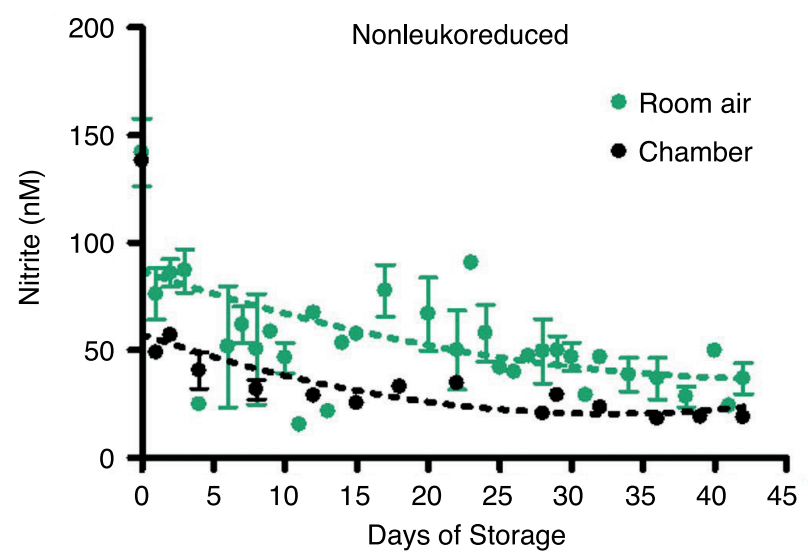

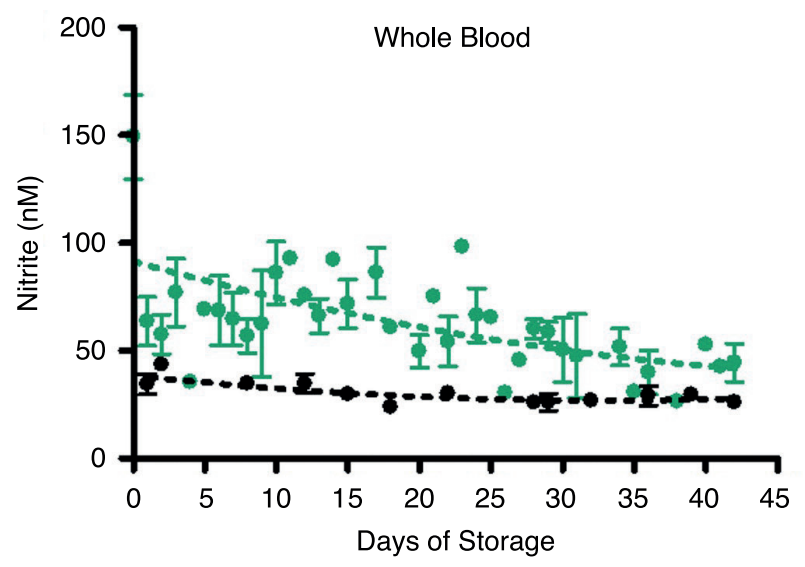

Supplemental Figure 2. Time-dependent room air and chamber changes in nitrite concentration for individual stored blood components; number of donors, $n=3$ (room air), $n=3$ (chamber).

a gradual increase in nitrite concentration from $62 \pm 6 \mathrm{nM}$ on day 1 to $140 \pm 7 \mathrm{nM}$ on day 42 . Saline stored in the argon chamber remained relatively steady over the storage period, as expected, showing a slight increase in nitrite concentration from $36 \pm 2 \mathrm{nM}$ on day 1 to $58 \pm 5 \mathrm{nM}$ on day 42 .

\section{Nitrate remains constant for the duration of storage}

In contrast to the results with nitrite ions, nitrate levels in $\mathrm{WB}$, in NLR and LR RBCs, and in supernatant samples remained steady for the duration of blood storage (Figure 4). Whole blood nitrate levels were slightly higher than either the non-leukoreduced or the leukoreduced $\mathrm{RBC}$ components stored either in air or in the argon chamber. In room air, WB nitrate concentration was about $47 \pm 2 \mu \mathrm{M}$, while NLR and LR nitrate concentrations were about $34 \pm 2 \mu \mathrm{M}$. For blood stored in the argon chamber, WB nitrate levels were lower than respective room air samples, with chamber nitrate remaining at about $37 \pm 3 \mu \mathrm{M}$. LR and NLR RBC nitrate levels in the chamber were unchanged when compared to LR and NLR RBCs stored in air, remaining at about $35 \pm 2 \mu \mathrm{M}$. Supernatant nitrate levels (measured after centrifugation of packed red cells or whole blood) followed the same trend as the blood samples, remaining steady for the duration of storage and exhibiting similar nitrate concentrations when stored in an argon chamber (data not shown).
$\mathrm{HbNO}$, SNOHb, and MetHb levels

The gas-phase chemiluminescence $\mathrm{I}_{3}{ }^{-}$assay was used to determine $\mathrm{SNOHb}$ and $\mathrm{HbNO}$ levels in blood components stored in both room air and chamber conditions. Figure 5 shows $\mathrm{HbNO}$ and $\mathrm{SNOHb}$ levels as detected by the NOA at two time points in the first hour following venisection. However, levels of $\mathrm{HbNO}$ and $\mathrm{SNOHb}$ were virtually undetectable 1 hour after blood collection and in stored blood thereafter.

A CO-oximeter was used to measure MetHb levels in all three blood components stored in both room air and chamber conditions. Figure 6 shows the gradual increase in MetHb from nearly $0.5 \%$ to just above $1 \%$ during the storage period. MetHb concentration is expressed as percentage of total hemoglobin concentration.

\section{Blood storage under standard conditions vs. hypoxic conditions}

Room air at $4{ }^{\circ} \mathrm{C}$ satisfied standard conditions for blood storage under current American Association of Blood Banks (AABB) Transfusion Medicine protocols; the argon chamber prevented gas exchange with ambient air and also mimicked blood storage under hypoxic conditions. Blood components stored in room air demonstrated a gradual rise in partial pressure of oxygen over the first three weeks 
A

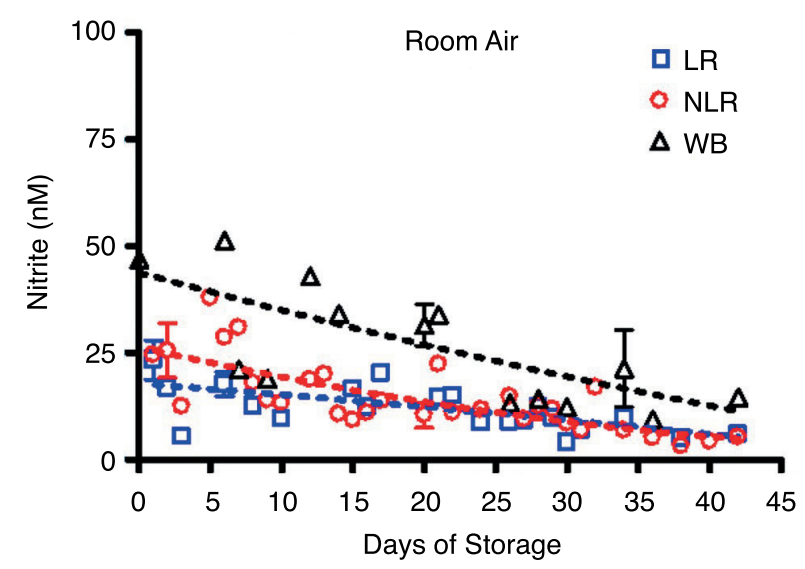

B

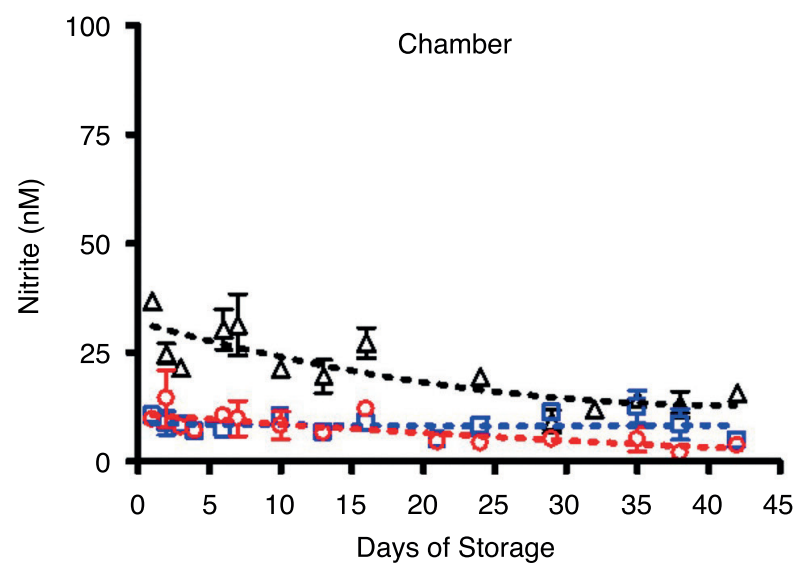

C

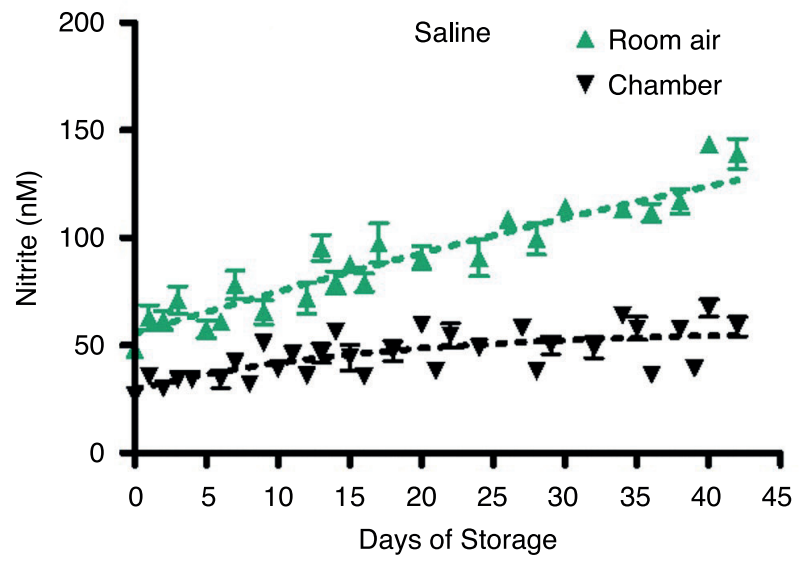

Figure 3. Nitrite concentration in supernatants and saline stored in room air or an argon chamber. Figure $3 \mathrm{~A}$ shows the nitrite concentration in supernatants stored in room air, number of donors, $n=3$, while Figure 3B shows the same for supernatants stored in an argon chamber, number of donors, $n=3$. Nitrite concentrations in saline controls stored under both conditions are shown in Figure 3C, number of donors, $\mathrm{n}=6$ (room air $\mathrm{n}=3$, argon chamber $\mathrm{n}=3$ ).

Nitrite concentration in supernatants and saline stored in room air and argon chamber

3 Data Files

http://dx.doi.org/10.6084/m9.figshare.96385

and leveled off thereafter. $\mathrm{pO}_{2}$ of blood components stored in the argon chamber remained at the levels of venous blood initially drawn or even showed a small decrease during storage. The $\mathrm{pH}$ of the samples stored in air was measured over the 42 days and gradually decreased from about 7.4 to below 6.5 (Supplemental Figure 3). This is consistent with previous reports ${ }^{35}$. The time in which $\mathrm{pH}$ levels fell below 6.5 differed among the blood products, with NLR RBC $\mathrm{pH}$ falling after the first 13-16 days, LR RBC after 23-24 days, and WB after about 38 days of storage.

\section{Inhibition of NO-producing enzymes}

It has been suggested that xanthine oxidase may take on the role of the main enzyme responsible for converting nitrite to vasoactive
NO in hypoxia ${ }^{36}$. In our study, however, several key NO-generating enzymes-NOS, carbonic anhydrase, and xanthine oxidase-were inhibited with L-NAME, acetazolamide, and oxypurinol, respectively. The amount of nitrite measured in the bags did not change as a result of NOS enzyme inhibition with L-NAME or carbonic anhydrase inhibition with acetazolamide (Supplemental Figure 4) over seven days of storage as compared to control LR or NLR red cells. The data for oxypurinol inhibition of xanthine oxidase were similar (data not shown).

\section{Discussion}

There is much concern, but also much controversy, about whether storage of red blood cells for transfusion decreases their therapeutic efficacy, or even leads to harm upon administration. The history of transfusion medicine has seen the development of technologies to allow increasingly extended storage of blood products, especially erythrocytes $^{37}$; in the last century, such advances have revolutionized medical practice by allowing blood to become a readily available therapeutic agent. In recent years, these advances have been called into question by the perception of possible deleterious effects 
A

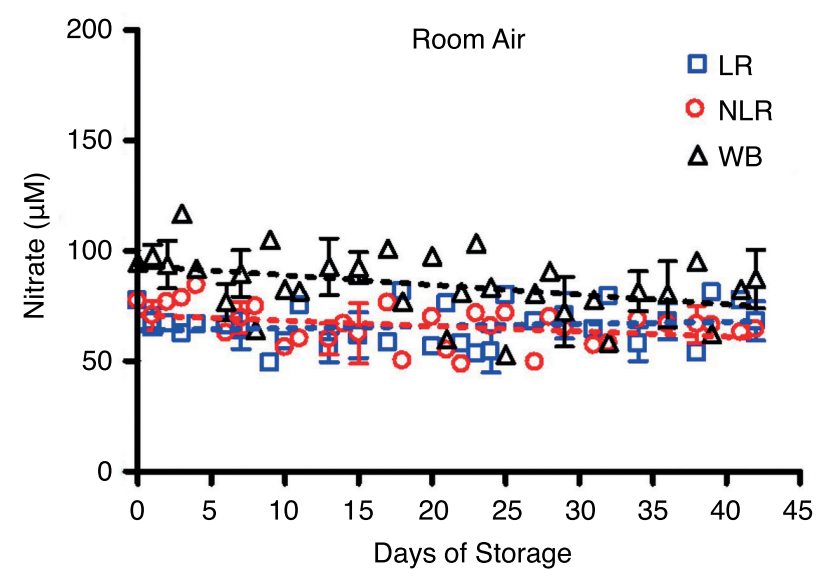

B

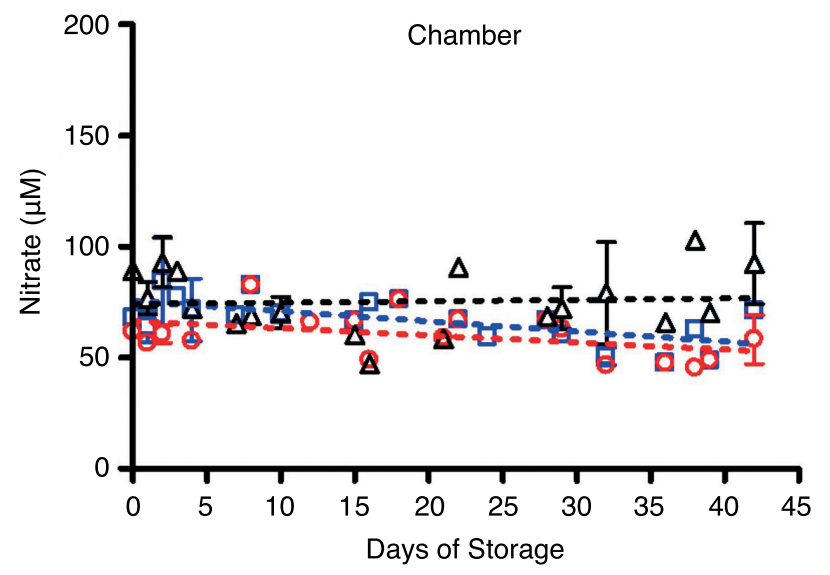

Figure 4. Effect of storage on nitrate concentration in blood stored for 42 days in room air (4A) or an argon chamber (4B); number of donors, $n=3(A), n=3$ (B).

Effect of storage on the three blood forms nitrate concentration

2 Data Files

http://dx.doi.org/10.6084/m9.figshare.96386

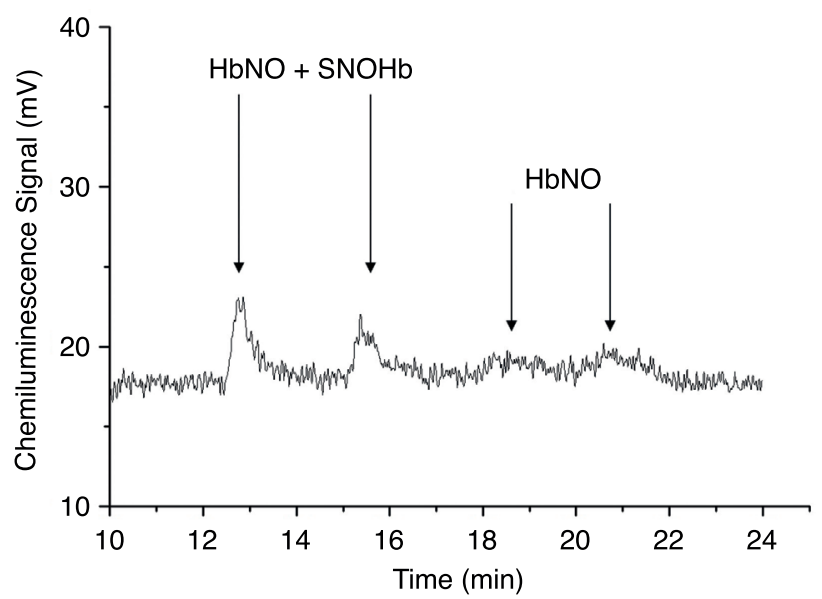

Figure 5. SNOHb levels in fresh blood (assay performed in the first hour after venisection). Gas-phase chemiluminescence signals used to determine $\mathrm{SNOHb}$ concentration. The peaks from two samples in the first 20 minutes of storage are shown; $\mathrm{SNOHb}$ concentration is ascertained by subtracting the $\mathrm{HbNO}$ peak from the composite of $\mathrm{SNOHb}$ plus $\mathrm{HbNO}$ after treatment with $\mathrm{HgCl}_{2}$ and acid sulfanilamide. The values of $\mathrm{SNOHb}$, near the sensitivity of the method, are less than $30 \mathrm{nM}$, while $\mathrm{HbNO}$ is barely detectable. Neither peak was detected after $1 \mathrm{hr}$ of storage.

\section{$\mathrm{HbNO}$ and SNOHb levels}

1 Data File

http://dx.doi.org/10.6084/m9.figshare.96387 of long-stored blood as compared to relatively new units of blood. Such negative effects, which are said to be associated with a "storage lesion", have been ascribed to some of the many biochemical changes that occur upon storage, including depletion of 2,3-DPG, ATP, and potassium ions, or even cellular changes, including increased rigidity or hemolysis, with resultant increases in free hemoglobin and iron in the transfusion recipients ${ }^{1,2,37}$. Although no significant hemolysis was seen in this study, a recent finding indicates that there may be some increase during the final week of storage ${ }^{38}$.

Clearly, many of these storage-related red cell changes, which could affect blood flow and oxygen delivery in the recipients, reverse rapidly upon infusion, and probably account for the fact that survival of $75 \%$ of transfused cells at 24 hours can be used as an achievable criterion for efficacy following storage ${ }^{39}$. (However, one might imagine that such in vivo repletion might not be rapid enough to avoid deleterious effects with very large volume transfusions). Indeed, the clinical evidence for blood age-associated transfusion complications is itself uncertain. It is clear that any such effects are relatively small compared to the efficacy of transfusions, which likely explains the difficulty of convincingly demonstrating them in small trials, where there are many confounding variables. However, in an era of therapy optimization, it is very important that we examine whether prolonged blood storage causes any changes, reversible or irreversible, that may interfere with the goals of transfusion medicine.

The importance of NO and the related oxides of nitrogen to determining blood flow and other biological phenomena has led to widespread focus on the role of NO in physiology and pathophysiology, and as of late, also during blood storage. It has long been recognized that both intraerythrocytic and free hemoglobin readily destroy NO. In a recently published reviews, a causal relationship between hemolysis-dependent changes in NO functionality and the storage lesion was presented, and the importance of contextual understanding of these changes through NO metabolites is addressed ${ }^{40,41}$. The recent recognition that red cells may transduce NO bioactivity by transporting NO in an endocrine-like fashion ${ }^{42}$ has focused interest 
A

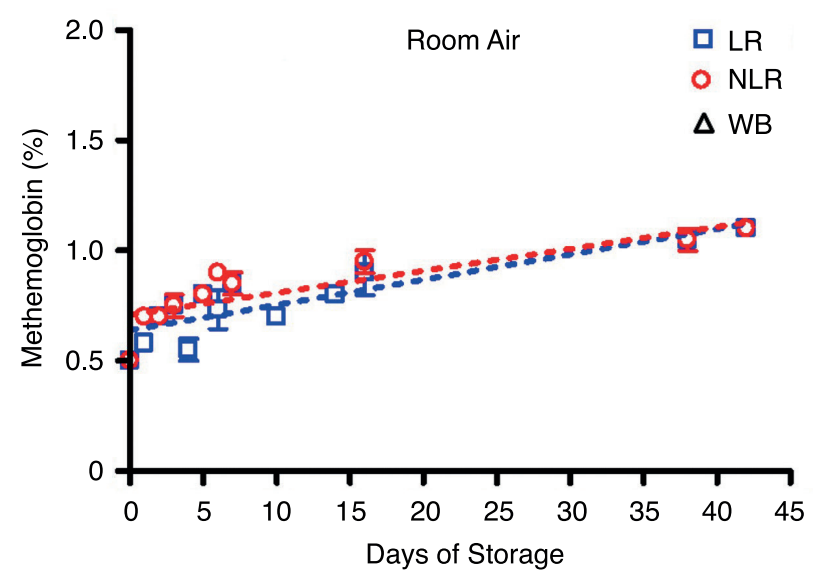

B

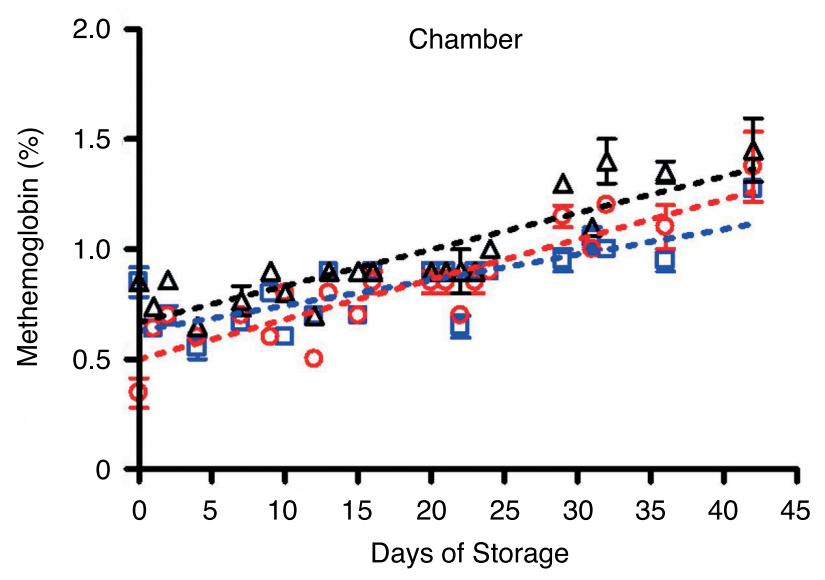

Figure 6. Change in MetHb levels in room air (6A) and chamber (6B) samples over 42 days of storage; number of donors, $n=2$ (A), $n=2(B)$.

MetHb levels in room air and argon chamber

2 Data Files

http://dx.doi.org/10.6084/m9.figshare.96388

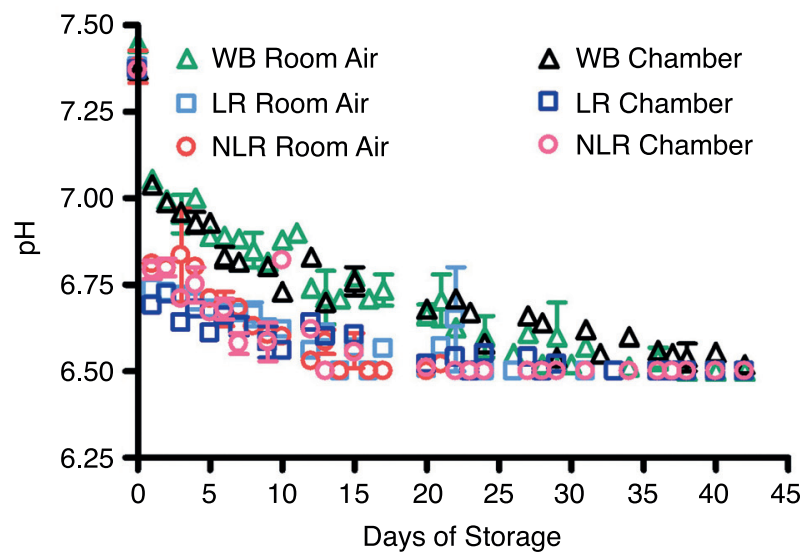

Supplemental Figure 3. Room air and argon chamber comparisons of $\mathrm{pH}$ levels in stored blood; number of donors, $\mathbf{n}=\mathbf{3}$ (room air), $\mathbf{n = 3}$ (chamber). Note: i-STAT apparatus does not detect $\mathrm{pH}$ levels below 6.5; values read as $<6.5$ were plotted at 6.5.

Room air and argon chamber comparisons of pH levels in stored blood

2 Data Files

http://dx.doi.org/10.6084/m9.figshare.96389

on measuring parameters related to these processes in stored red cells, as they may balance the destructive mechanisms. Much recent work has focused on the ability of deoxyhemoglobin and other red cell-related proteins, xanthine oxidoreductase in particular ${ }^{43}$, to reduce red cell or plasma nitrite ions to NO. A recent study of NO-related metabolic changes during platelet storage also suggests the possibility of platelet consumption of nitrite ${ }^{26}$. An older hypothesis, in which $\mathrm{NO}$ forms S-nitrosohemoglobin ( $\mathrm{SNOHb}$ ) upon reaction with oxyhemoglobin but then dissociates upon deoxygenation, has some adherents, although recent experiments involving transgenic animal models seem to largely negate this theory ${ }^{44}$.

Nitrite in red cells and plasma may be considered as the primary storage form of NO because of its relative abundance in blood and increasing evidence of its physiological and pharmacological importance. Nitrite and nitrate ions are the major oxidation products of NO metabolism and are produced in the body by reaction with oxygen, hemoglobin, ceruloplasmin and possibly other molecules $^{45}$. In addition, nitrite and nitrate are ingested with food; nitrite can also be produced from nitrate by salivary bacteria ${ }^{46}$. Measurement of nitrite levels in blood have been suggested as an index of NO bioavailability for epidemiological studies of cardiovascular disease severity ${ }^{47}$.

Our approach to the question of NO bioavailability in stored red cells has been to measure nitrite and nitrate as a function of duration and conditions of storage as occurs in transfusion practice. Our major finding is that, although much red cell nitrite is rapidly lost during the first few hours of storage, nitrite levels continue to deplete, albeit at a much slower rate, to a clear plateau of about $44 \mathrm{nM}$ in the last two weeks of storage. This phenomenon is almost identical in red cells stored with or without leukodepletion and those stored as whole blood; this suggests that interactions with white blood cells and platelets do not significantly impact nitrite metabolic processes. However, while storage of blood in a closed chamber under argon did not change the progression of the nitrite depletion, this environment did lower overall nitrite values in a nearly uniform fashion, to a final concentration of about $20 \mathrm{nM}$.

Red cell nitrate levels remained virtually unchanged from day 1 to day 42 , at around $35 \mu \mathrm{M}$ (approximately $1000 \mathrm{X}$ the final concentration of nitrite), and were identical for red cells stored as leukoreduced, non-leukoreduced, and whole blood. The storage conditions, 
A

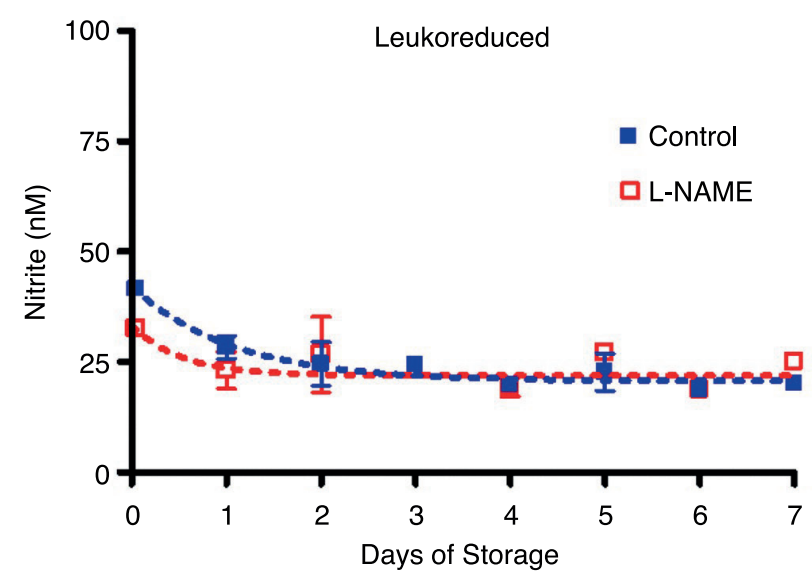

C

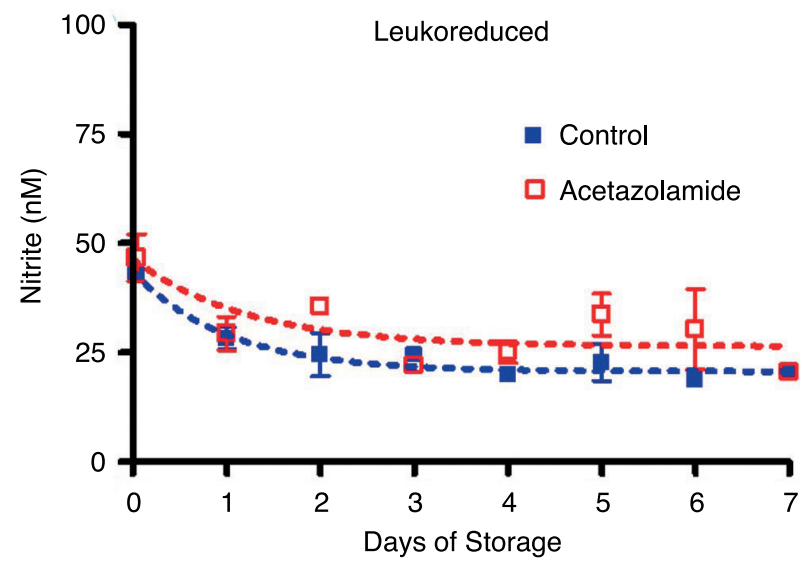

B

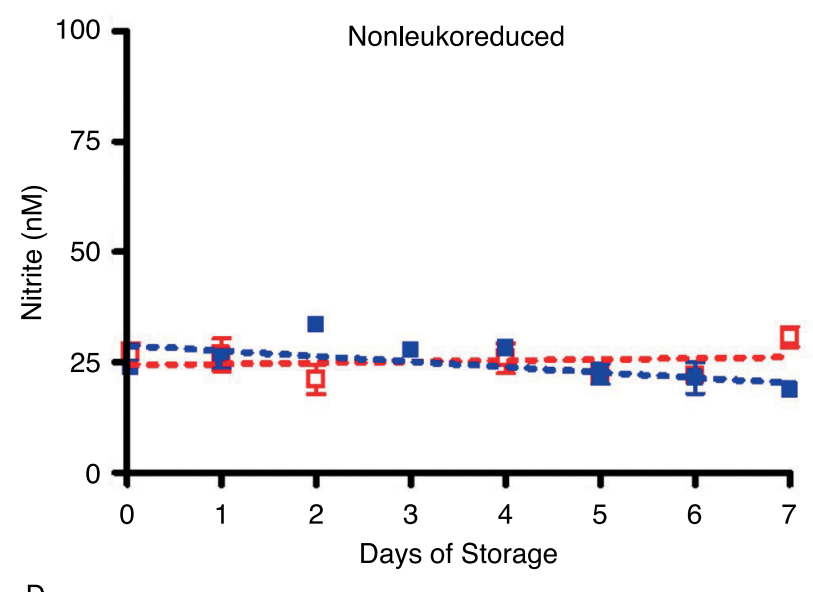

D

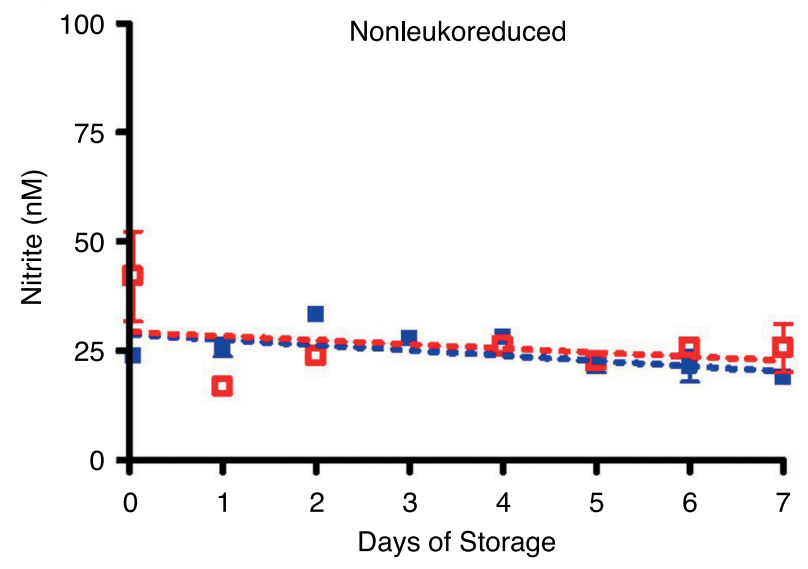

Supplemental Figure 4. Enzyme inhibition of NO production. Inhibition of NOS with L-NAME in leukoreduced RBCs (S4A) and non-leukoreduced RBCs (S4B); number of donors, $\mathbf{n}=\mathbf{2}$. S4C and S4D show inhibition of carbonic anhydrase with acetazolamide in leukoreduced RBCs and in non-leukoreduced RBCs, respectively; number of donors, $n=2$. All bags were stored in room air at $4^{\circ} \mathrm{C}$ for 7 days.

\section{Inhibition of NO-producing enzymes}

2 Data Files

http://dx.doi.org/10.6084/m9.figshare.96390

whether room air or argon chamber, did not affect these measurements. As expected, metHb concentrations under all experimental conditions remained around $1 \%$, as previously shown ${ }^{34}$. Levels of $\mathrm{SNOHb}$ during the first hour of analysis were barely detectable by gas-phase chemiluminescence after triiodide treatment, and were consequently unquantifiable.

Our nitrite results, which showed that nitrite levels stabilized and remained stable at nonzero values, were surprising. From previous studies of the reaction of hemoglobin with nitrite in vitro, we would predict that nitrite would largely disappear over the course of storage. Although we cannot offer a complete explanation for the mechanism of nitrite retention in the red cell, our investigation of this effect has led to several conclusions. First, we addressed the potential role of several enzymes implicated in NO cycle-NOS, xanthine oxidase, and carbonic anhydrase. Nitrite levels did not change upon inhibition of these enzymes, indicating that they are not likely contributors to the maintenance of the low nitrite concentrations. Second, HbNO is also an unlikely source of nitrite, as it is nearly unquantifiable after twenty minutes, with a half-life of $\sim 79$ minutes $^{23}$. Third, reduction of nitrate to nitrite also seems unlikely, since mammalian processes to account for such a reaction have not been described; however, the fact that nitrate remains steady does not necessarily exclude this process, as only a one-tenth of $1 \%$ change in nitrate could account for the maintenance of these nitrite levels. Finally, while bacteria are known to synthesize nitrite, bacterial contamination may be ruled out because standard blood storage protocol virtually eliminates the risk of such contamination. On the other hand, several explanations may account for at least part of this nitrite retention. Greater depletion of nitrite found in the argon chamber samples raises the possibility that nitrogen reactive species may enter the stored blood via diffusion from the atmosphere through the gas-permeable PVC bags, as confirmed by our saline solutions. Atmospheric nitrogen reactive species may therefore account for some of the nitrite that remains. Other potential mechanisms to explain nonzero values of nitrite at 42 days include the possibility of nitrite binding to $\mathrm{RBC}$ proteins (such as band 
3 proteins or other members of the cytoskeletal protein scaffold via ionic interactions that could effectively shield nitrite from reacting with hemoglobin), hemoglobin-nitrite ionic interactions, and formation of nitrite-methemoglobin complexes.

NO and its metabolic products are likely to play an important role in maintenance of banked blood, as effective agents for transfusion therapies. Nitrite seems to be a source of great NO bioactivity that remains present in the blood for the duration of storage. Nitrate is also present in relative abundance to nitrite throughout storage. The presence of these metabolites in red cells up to 42 days of storage provides the possibility that maintenance of $\mathrm{NO} /$ nitrite levels and NO bioactivity is likely to occur via the nitrate-nitrite-NO pathway.

\section{Author contributions}

Melissa A Qazi performed data collection, statistical analysis, and wrote the manuscript. Fabiola Rizzatti developed the project design, performed data collection and statistical analysis, and edited the manuscript. Nathawut Sibmooh and Barbora Piknova provided technical assistance with data collection and edited the manuscript.
David Stroncek provided access to the NIH Blood Bank and Department of Transfusion Medicine facilities and assistance with DTM procedures. Alan N Schechter designed the project and edited the manuscript.

\section{Competing interests}

Alan N Schechter has a patent on therapeutic use of nitrite salts. Melissa A Qazi, Fabiola Rizzatti, Barbora Piknova, Nathawut Sibmooh, and David Stroncek have no conflicts of interest to disclose.

\section{Grant information}

The study was funded by and received research support from the Molecular Medicine Branch, NIDDK, NIH and the Department of Transfusion Medicine, Clinical Center, NIH.

The funders had no role in study design, data collection and analysis, decision to publish, or preparation of the manuscript.

\section{Acknowledgments}

We would like to say a special thanks to Barbara Bryant for graciously offering her technical expertise and support during the completion of this work.
1. Tinmouth A, Ferguson D, Yee IC, et al.: Clinical consequences of red cell storage in the critically ill. Transfusion. 2006; 46(11): 2014-2027. PubMed Abstract | Publisher Full Text

2. Klein HG, Spahn DR, Carson JL: Red blood cell transfusion in clinical practice. Lancet. 2007; 370(9585): 415-426. PubMed Abstract | Publisher Full Tex

3. Purdy FR, Tweeddale MG, Merrick PM: Association of mortality with age of blood transfused in septic ICU patients. Can J Anaesth. 1997; 44(12): 1256-1261. PubMed Abstract | Publisher Full Text

4. Offner PJ, Moore EE, Biffl WL, et al:: Increased rate of infection associated with transfusion of old blood after severe injury. Arch Surg. 2002; 137(6): 711-717. PubMed Abstract | Publisher Full Text

5. Koch CG, Li L, Sessler DI, et al:: Duration of red-cell storage and complications after cardiac surgery. N Engl J Med. 2008; 358(12): 1229-1239. PubMed Abstract | Publisher Full Text

6. Leal-Noval SR, Jara-Lopez I, Garcia-Garmendia JL, et al.: Influence of erythrocyte concentrate storage time on postsurgical morbidity in cardiac surgery patients. Anesthesiology. 2003; 98(4): 815-822. PubMed Abstract | Publisher Full Text

7. Luten M, Roerdinkholder-Stoelwinder B, Schaap NP, et al:: Survival of red blood cells after transfusion: a comparison between red cells concentrates of different storage periods. Transfusion. 2008; 48(7): 1478-1485. PubMed Abstract | Publisher Full Text

8. Yap CH, Lau L, Krishnaswamy M, et al.: Age of transfused red cells and early outcomes after cardiac surgery. Ann Thorac Surg. 2008; 86(2): 554-559. PubMed Abstract | Publisher Full Text

9. Edgren G, Kamper-Jorgensen M, Eloranta S, et al.: Duration of red blood cell storage and survival of transfused patients (CME). Transfusion. 2010; 50(6): 1185-1195

PubMed Abstract | Publisher Full Text | Free Full Text

10. Cornet AD, Zwart E, Kingma SD, et al:: Pulmonary effects of red blood cell transfusion in critically ill, non-bleeding patients. Transfus Med. 2010; 20(4): 221-226.

PubMed Abstract | Publisher Full Text

11. Valeri CR, Hirsch NM: Restoration in vivo of erythrocyte adenosine triphosphate, 2,3-diphosphoglycerate, potassium ion, and sodium ion concentrations following the transfusion of acid-citrate-dextrose-stored human red blood cells. J Lab Clin Med. 1969; 73(5): 722-733. PubMed Abstract

12. Ho J, Sibbald WJ, Chin-Yee IH: Effects of storage on efficacy of red cell transfusion: when is it not safe? Crit Care Med. 2003; 31(12 Suppl): S687-S697. PubMed Abstract | Publisher Full Text
13. Ignarro LJ, Buga GM, Wood KS, et al:: Endothelium-derived relaxing factor produced and released from artery and vein is nitric oxide. Proc Natl Acad Sci U S A. 1987; 84(24): 9265-9269. PubMed Abstract | Publisher Full Text | Free Full Text

14. Moncada A, Palmer RM, Higgs EA: Nitric oxide: physiology, pathophysiology, and pharmacology. Pharmacol Rev. 1991; 43(2): 109-142. PubMed Abstract

15. Ignarro LJ, Napoli C: Novel features of nitric oxide, endothelial nitric oxide synthase, and atherosclerosis. Curr Atheroscler Rep. 2004; 6(4): 281-287. PubMed Abstract | Publisher Full Text

16. Kleinbongard $\mathrm{P}$, Schulz $\mathrm{R}$, Rassaf $\mathrm{T}$, et al.: Red blood cells express a functional endothelial nitric oxide synthase. Blood. 2006; 107(7): 2943-2951.

PubMed Abstract | Publisher Full Text

17. Cokic VP, Schechter AN: Effects of Nitric Oxide on Red Blood Cell Development and Phenotype. Curr Top Dev Biol. 2008; 82: 169-215. PubMed Abstract | Publisher Full Text

18. Zweier JL, Wang P, Samouilov A, et al.: Enzyme-independent formation of nitric oxide in biological tissues. Nat Med. 1995; 1(8): 804-809. PubMed Abstract | Publisher Full Text

19. Cosby K, Partovi KS, Crawford JH, et al:: Nitrite reduction to nitric oxide by deoxyhemoglobin vasodilates the human circulation. Nat Med. 2003; 9(12): 1498-1505. PubMed Abstract | Publisher Full Text

20. Dejam A, Hunter CJ, Schechter AN, et al:: Emerging role of nitrite in human biology. Blood Cells Mol Dis. 2004; 32(3): 423-429. PubMed Abstract | Publisher Full Text

21. Dejam A, Hunter CJ, Pelletier MM, et al:: Erythrocytes are the major intravascular storage sites of nitrite in human blood. Blood. 2005; 106(2): 734-739. PubMed Abstract | Publisher Full Text | Free Full Text

22. Dejam A, Hunter CJ, Tremonti C, et al:: Nitrite infusion in humans and nonhuman primates: endocrine effects, pharmacokinetics, and tolerance formation. Circulation. 2007; 116(16): 1821-1831. PubMed Abstract | Publisher Full Text

23. Sibmooh N, Piknova B, Rizzatti F, et al:: Oxidation of Iron-nitrosyl-hemoglobin by dehydroascorbic acid releases nitric oxide to form nitrite in human erythrocytes. Biochemistry. 2008; 47(9): 2989-2996. PubMed Abstract | Publisher Full Text

24. Rother RP, Bell L, Hillmen $\mathrm{P}$, et al:: The clinical sequelae of intravascular hemolysis and extracellular plasma hemoglobin: a novel mechanism of human disease. JAMA. 2005; 293(13): 1653-1662. PubMed Abstract | Publisher Full Text 
25. Srihirun $\mathrm{S}$, Sriwantana $\mathrm{T}$, Unchern $\mathrm{S}$, et al:: Platelet inhibition by nitrite is dependent on erythrocytes and deoxygenation. PLoS One. 2012; 7(1): e30380. PubMed Abstract | Publisher Full Text | Free Full Text

26. Park JW, Piknova B, Kurtz J, et al.: Effect of storage on levels of nitric oxide metabolites in platelet preparations. Transfusion. 2013; 53(3): 637-44. PubMed Abstract | Publisher Full Text | Free Full Text

27. Gladwin MT, Wang X, Reiter CD, et al:: S-Nitrosohemoglobin is unstable in the reductive erythrocyte environment and lacks $\mathrm{O}_{2} / \mathrm{NO}$-linked allosteric function. J Biol Chem. 2002; 277(31): 27818-27828.

PubMed Abstract | Publisher Full Text

28. Rassaf T, Bryan NS, Kelm M, et al: Concomitant presence of N-nitroso and S-nitroso proteins in human plasma. Free Radic Biol Med. 2002; 33(11): 1590-1596.

PubMed Abstract | Publisher Full Text

29. Winslow RM, Intaglietta M: Red cell age and loss of function: advance or SNO-job? Transfusion. 2008; 48(3): 411-414. PubMed Abstract | Publisher Full Text

30. Yang BK, Vivas EX, Reiter CD, et al:: Methodologies for the sensitive and specific measurement of S-nitrosothiols, iron-nitrosyls, and nitrite in biological samples. Free Radic Res. 2003; 37(1): 1-10. PubMed Abstract | Publisher Full Text

31. Pelletier MM, Kleinbongard P, Ringwood L, et al:: The measurement of blood and plasma nitrite by chemiluminescence: pitfalls and solutions. Free Radic Biol Med. 2006; 41(4): 541-548.

PubMed Abstract | Publisher Full Text

32. Yu LB, Dong XS, Sun WZ, et al.: Effect of a nitric oxide synthase inhibitor NG-nitro-L-arginine methyl ester on invasion of human colorectal cancer cell line SL-174T. World J Gastroenterol. 2005; 11(40): 6385-6388. PubMed Abstract

33. Maren TH: Current status of membrane-bound carbonic anhydrase. Ann NY Acad Sci. 1980; 341: 246-258 PubMed Abstract | Publisher Full Tex

34. Babbs CF, Salaris SC, Turek JJ: Cytochemical studies of hydrogen peroxide generation in postischemic hepatocytes. Am J Physio 1991; 260(1 Pt 2): H123-129. PubMed Abstract

35. Picker SM, Radojska SM, Gathof BS: In vitro quality of red blood cells (RBCs) collected by multicomponent apheresis compared to manually collected RBCs during 49 days of storage. Transfusion. 2007; 47(4): 687-696. PubMed Abstract | Publisher Full Text

36. Casey DB, Badejo AM Jr, Dhaliwal JS, et al: Pulmonary vasodilator responses to sodium nitrite are mediated by an allopurinol-sensitive mechanism in the rat. Am J Physiol Heart Circ Physiol. 2009; 296(2): H524-533. PubMed Abstract | Publisher Full Text | Free Full Text

37. Hess JR: An update on solutions for red cell storage. Vox Sang. 2006; 91(1): 13-19.

PubMed Abstract | Publisher Full Text

38. Hess JR, Sparrow RL, van der Meer PF, et al.: Red blood cell hemolysis during blood bank storage: using national quality management data to answer basic scientific questions. Transfusion. 2009; 49(12): 2599-2603.

PubMed Abstract | Publisher Full Text

39. Lockwood WB, Leonard J, Liles SL, et al:: Storage, monitoring, pretransfusion processing, and distribution of blood components. In: Roback JD, Combs MR, Grossman BJ, Hillyer CD, eds. Technical Manual, $16^{\text {th }}$ edition. Bethesda, MD: AABB; 2008; 283-299.

Reference Source

40. Gladwin MT, Kim-Shapiro DB: Storage lesion in banked blood due to hemolysis-dependent disruption of nitric oxide homeostasis. Curr Opin Hematol. 2009; 16(6): 515-523.

PubMed Abstract | Publisher Full Text

41. Schechter AN, Gladwin MT: Hemoglobin and the paracrine and endocrine functions of nitric oxide. N Engl J Med. 2003; 348(15): 1483-1485. PubMed Abstract | Publisher Full Text

42. Li H, Samouilov A, Liu X, et al.: Characterization of the magnitude and kinetics of xanthine oxidase-catalyzed nitrite reduction.Evaluation of its role in nitric oxide generation in anoxic tissues. J Biol Chem. 2001; 276(27): 24482-24489. PubMed Abstract | Publisher Full Text

43. Isbell TS, Sun CW, Wu LC, et al.: SNO-Hemoglobin is not essential for red blood cell-dependent hypoxic vasodilation. Nat Med. 2008; 14(7): 773-777. PubMed Abstract | Publisher Full Text | Free Full Text

44. Lundberg JO, Weitzberg E, Gladwin MT: The nitrate-nitrite-nitric oxide pathway in physiology and therapeutics. Nat Rev Drug Discov. 2008; 7(2): 156-167. PubMed Abstract | Publisher Full Text

45. Kelm M: Nitric oxide metabolism and breakdown. Biochim Biophys Acta. 1999; 1411(2-3): 273-289.

PubMed Abstract | Publisher Full Text

46. Kleinbongard P, Dejam A, Lauer T, et al:: Plasma nitrite concentrations reflect the degree of endothelial dysfunction in humans. Free Radic Biol Med. 2006; 40(2): 295-302. PubMed Abstract | Publisher Full Text

47. Kanias T, Wang L, Lippert A, et al.: Red blood cell endothelial nitric oxide synthase does not modulate red blood cell storage hemolysis. Transfusion. 2013; 53(5): 981-9.

PubMed Abstract | Publisher Full Text 


\section{Open Peer Review}

\section{Current Peer Review Status:}

\section{Version 1}

Reviewer Report 12 November 2012

https://doi.org/10.5256/f1000research.212.r463

(C) 2012 Zweier J. This is an open access peer review report distributed under the terms of the Creative Commons Attribution License, which permits unrestricted use, distribution, and reproduction in any medium, provided the original work is properly cited.

\section{Jay Zweier}

Davis Heart \& Lung Research Institute, The Ohio State University, Columbus, OH, USA

Overall this research article is well written and clear for the most part. I do however have 2 minor comments for the authors to think about:

1. It would be interesting to include data on the time course and extent of hemolysis as this may contribute to toxicity and also the nitrite depletion.

2. The presentation of Figure 5 is unclear. The authors should better describe and explain this figure. 2 sets of 2 peaks are seen at different times. Please explain the times shown for each peak. Please explain each peak and exactly what it is and how it was measured. It is noted that 2 samples are shown, which correspond to which peak? What is the difference between these 2 samples? How does this relate to the time shown? Were there quantitative standards that were run for $\mathrm{HbNO}$ and $\mathrm{SNOHb}$ ? Could some portion of these small peaks arise from residual nitrite?

Competing Interests: No competing interests were disclosed.

I confirm that I have read this submission and believe that I have an appropriate level of expertise to confirm that it is of an acceptable scientific standard.

\section{Author Response 19 Nov 2012}

Barbara Piknova, Molecular Medicine Branch, National Institutes of Diabetes and Digestive and Kidney Diseases, National Institutes of Health, USA

We thank Dr Zweier for his approval and comments.

1. It is true that hemoglobin from RBCs lyzed during the storage over 42 day would significantly alter the amount of nitrite measured in preparation, as hemoglobin is a very potent nitrite oxidase. However, during our study we did not observe any significant 
hemolysis in our preparations (in fact, using spectrophotometry, $\mathrm{Hb}$ was below our detection limits in RBC supernatants) and data from other studies from NIH blood bank were also in favor of only minor hemolysis occurring during the careful handling of stored blood.

2. Figure 5 is an example of our raw chemiluminescence data i.e. the output from the NOA analyzer. The principle and application of this method is described in details in Piknova B and Schechter AN (2011) Measurement of nitrite in blood samples using the ferricyanidebased hemoglobin oxidation assay. Methods Mol Biol. 704:39-56.

In this method, reaction vessel is filled with nitrite/ $\mathrm{HbNO} / \mathrm{SNOHb}$-reducing tri-iodide solution and connected to NOA analyzer. Carrier gas $(\mathrm{He})$ passing through the reaction solution carries NO from reduced "NOx-compounds" into reaction chamber inside the NOA analyzer, where NO reacts with ozone (made by high-voltage generator from oxygen) and forms NO*. When excited NO* molecule returns to its main electron levels, a photon is emitted in red-light region and registered by photomultiplier. The reaction ratio is $1: 1$ in NO:NO* and also in NO*:photon, which allows to very precise quantification of NO and therefore, original nitrite/HbNO/SNOHb species present in sample. The specificity towards $\mathrm{HbNO}$ and $\mathrm{SNOHb}$ is achieved by different pre-treatments of sample and by subtraction of known components from composite peaks. In Figure 5 we tried to illustrate that peaks obtained for $\mathrm{SNOHb}+\mathrm{HbNO}$ were already somehow on the detection limit of our method and that trying to quantify them would lead to significant errors. Therefore, we did not proceed to quantification of these compounds, as we know from our previous experiments that levels comparable with Figure 5 would be from $\sim 20 \mathrm{nM} \mathrm{HbNO}$ and SNOHb, which was really the low detection limit. Times shown on Figure 5 are for illustrative purposes only, subsequent injections of different samples into vessel are possible whenever the previous sample readings returns to the baseline.

Competing Interests: No competing interests were disclosed.

Reviewer Report 29 October 2012

https://doi.org/10.5256/f1000research.212.r462

(C) $2012 \mathrm{Kelm}$ M. This is an open access peer review report distributed under the terms of the Creative Commons Attribution License, which permits unrestricted use, distribution, and reproduction in any medium, provided the original work is properly cited.

\section{Malte Kelm}

Division of Cardiology, Pulmonology, and Vascular Medicine Medical Faculty, University Duesseldorf, Duesseldorf, Germany

In the present study, Qazi et al. examined the effect of storage on levels of nitric oxide derivatives in blood components.

They examined the biochemical changes in the nitric oxide metabolism in red blood cell 
transfusions and reported that nitrite concentrations initially decreased rapidly and stabilized afterwards for up to 42 days. Under hypoxic conditions in an argon chamber there are even less nitrite levels compared to room air.

In my opinion the data provided by the authors is interesting as they show a long-term view on nitrite levels in red blood cell transfusions and provide valuable information about optimizing the preservation of stored blood. These findings definitely extend the current knowledge base in the field.

Competing Interests: No competing interests were disclosed.

I confirm that I have read this submission and believe that I have an appropriate level of expertise to confirm that it is of an acceptable scientific standard.

Reviewer Report 25 October 2012

https://doi.org/10.5256/f1000research.212.r461

(C) 2012 Weitzberg E. This is an open access peer review report distributed under the terms of the Creative Commons Attribution License, which permits unrestricted use, distribution, and reproduction in any medium, provided the original work is properly cited.

\section{Eddie Weitzberg}

Department of Physiology and Pharmacology, Karolinska Institutet and Hospital, Stockholm, Sweden

Competing Interests: No competing interests were disclosed.

I confirm that I have read this submission and believe that I have an appropriate level of expertise to confirm that it is of an acceptable scientific standard.

Reviewer Report 24 October 2012

https://doi.org/10.5256/f1000research.212.r460

(C) 2012 Lundberg J. This is an open access peer review report distributed under the terms of the Creative Commons Attribution License, which permits unrestricted use, distribution, and reproduction in any medium, provided the original work is properly cited.

\section{Jon O. Lundberg}

Department of Physiology and Pharmacology, Karolinska Institutet and Hospital, Stockholm, Sweden 
Competing Interests: No competing interests were disclosed.

I confirm that I have read this submission and believe that I have an appropriate level of expertise to confirm that it is of an acceptable scientific standard.

Reviewer Report 23 October 2012

https://doi.org/10.5256/f1000research.212.r459

(C) 2012 Dejam A. This is an open access peer review report distributed under the terms of the Creative Commons Attribution License, which permits unrestricted use, distribution, and reproduction in any medium, provided the original work is properly cited.

\section{Andre Dejam}

Department of Internal Medicine, Brigham and Women's Hospital, Boston, MA, USA

I read with great interest the article by Dr. Schechter's group in DC on the effect of storage on levels of nitric oxide derivatives in blood components.

I approve this article as it extends the current knowledge base in the field.

Competing Interests: No competing interests were disclosed.

I confirm that I have read this submission and believe that I have an appropriate level of expertise to confirm that it is of an acceptable scientific standard.

The benefits of publishing with F1000Research:

- Your article is published within days, with no editorial bias

- You can publish traditional articles, null/negative results, case reports, data notes and more

- The peer review process is transparent and collaborative

- Your article is indexed in PubMed after passing peer review

- Dedicated customer support at every stage

For pre-submission enquiries, contact research@f1000.com 